\title{
İnfertil kadınlarda Chlamydia trachomatis seroprevalansı ve güncel durumun irdelenmesi "yazarın yanıtı"
}

\author{
Rasih Felek
}

Sayın Editör;

"Infertil kadınlarda Chlamydia trachomatis seroprevalansı ve güncel durumun irdelenmesi" başıkı makalemle ilgili katkısı ve eleştirileri için sayın yazara teşekkür ederim $[1,2]$.

Ülkemizde klamidya enfeksiyonlarının yaygınığı ve komplikasyonları hakkında 30 yılı aşkın süredir raporlar yayınlanmaktadır. Sunulan makalede, mevcut literatüre internet üzerinden yapılan taramalardan ulaşılabilmiştir. Bu sorunun aşılması için ülkemize son yıllarda Ulakbim TR-Dizin, bu konuda yoğun veri kataloglaması yapmakta, bilimsel taramalara açmaktadır. Sunulan makalede sadece infertil hastalara ait Chlamydia trachomatis antijen ve antikoru araştırmaları alınmış, bu konudaki kaynakların kullanılmasına özen gösterilmiştir. Ayrıca, rutin pratik işlemlerde, tüp bebek tedavisi rutininde, klamidya antikorları taramasının rutin yapılmaması nedeni ile bu araştırma verilerinin önemli olduğu düşüncesindeyim.

Ülkemizde yapılan tıpta uzmanlık tezleri verilerinin, süreye bakılmaksızın bilimsel alanda paylaşıması, ilgili konuda yeni araştırmaların planlanması (güç analizi gibi) açısından yararlıdır. Sunulan araştırmanın özü, 1995 yılında Atatürk Üniversitesi kurumunda yapılmış olan tıpta uzmanlık tez çalışmasıdır [3]. Bu araştırmaya ait bilimsel kongre sunumu yine araştırmada bulunan klinik mikrobiyolog ve kadın doğum uzmanları ile birlikte 1995 yılında Türk Mikrobiyoloji Kongresi'nde sunulmuştur [4]. Poster verileri zamanına ait veriler olup, günümüzden 25 sene önceye aittir, güncel değildir [4]. Çalışma verilerinin toplandığı döneme ait etik görüş ve yaklaşım; tez raporunda da belirtildiği şekilde, "iyi klinik uygulamalar" altyapısındadır. "İyi klinik uygulamalar" klavuzu, sunulan araştırmanın yapılmasından sonra, 15 Temmuz 2014 tarihinde T.C. Sağlık Bakanlığı tarafından yayınlanmıştır [5]. Sunulan makalede ise, 1995 yılında analizi tamamlanmış olan veriler, retrospektif olarak ele alınmış ve güncel veriler ile karşılaştırılarak okuyucuya aktarılmıştır. Bu nedenle etik kurul görüşü başvurusu yazarın halen çalışmakta olduğu kurum üzerinden yapılmış, verilerin dönemsel analizinin sunulmasına ait görüş alınmıştır (Akdeniz Üniversitesi Tıp Fakültesi Klinik Araştırmalar Etik Kurulu'ndan 14.02.2019 tarih ve 70904504/67 sayısı ile "sakınca" olmadığına dair görüş bildirilmiştir).

Sonuç olarak, ülkemizdeki bilimsel verilerin etik kurallar dahilinde yapılması, bu verilerin ulaşılabilir olmasının önemli olduğunu düşünmekteyim.

\section{Kaynaklar}

1. Felek R. İnfertil kadınlarda chlamydia trachomatis seroprevalansı ve güncel durumun irdelenmesi. 2020;13:149-154. https://dx.doi.org/10.31362/ patd. 529170

2. Tekin B, Bolatlı $T$, Alataş $E$, Şengül $M$, Akgün $Y$. Vajinal akıntılı kadınlarda, Neisseria gonorrhoeae ve chlamydia trachomatis antijenlerinin EIA yöntemiyle araştırılması. Osmangazi Üniversitesi Tıp Fakültesi Dergisi 1994;16:33-40.

3. Felek R. İnfertil hastalarda chlamydial antijen ve Ig G seropozitiflik üzerine bir araştırma. Atatürk Üniversitesi, Tıp Fakültesi, Mikrobiyoloji ve Klinik Mikrobiyoloji Anabilim Dalı, Yök Tez No:40213, 1995.

4. Felek R, Tuncel E, Aktaş O, Küçüközkan T. Erzurum'da fertil ve infertil kadınlarda Chlamydia trachomatis serovarları. 5. Ulusal İnfeksiyon Hastalıkları Kongresi, Kongre Kitabı: Klamidyalar ve Klamidya Enfeksiyonları, Türk Mikrobiyoloji Cemiyeti Yayın No:23;8:02, 1995;P70.

5. Türkiye İlaç ve Tıbbi Cihaz Kurumu. İyi klinik uygulamaları kılavuzu. Erişim adresi: https://www. titck.gov.tr/PortalAdmin/Uploads/UnitPageAttachment/ b607e1a453003.pdf. Erişim tarihi 15.07.2014 